\title{
Gender, Konsumsi Berita COVID-19 dan News Fatigue di Jakarta
}

\author{
Michelle Natasya dan Yearry Panji Setianto \\ Fakultas Ilmu Komunikasi, Universitas Multimedia Nusantara \\ michelle.natasya1@gmail.com
}

\begin{abstract}
In the current era of 'flood of information', people are competing to be the first to obtain and share information, especially that is related to the COVID-19 pandemic. Particularly for those who live in metropolitan areas like Jakarta (with the most COVID-19 cases per January 2021), who are always required to be up to date. FOMO (Fear of Missing Out), is feeling anxious or insecure about the possibility of losing or missing something. FOMO will cause someone to be more aggressive in accessing information which can ultimately lead to news fatigue, a condition where a person feels stressed or exhausted due to information overload. Researchers examine the differences of news fatigue practices based on gender in the context of the pandemic. This study uses Uses and Gratifications 2.0 theory along with the concept of news fatigue to news avoidance as well as news and gender. As a descriptive-qualitative study using a case-study method, we utilize media diary and in-depth interviews as our data collection strategy. The results indicate that female participants experienced news fatigue differently from male participants. In the context of the COVID-19 news, female participants felt they were more tired of this topic since most of the news was negative and being reported repeatedly. Their types of jobs and the double burden of participants play an important role in the practice of news fatigue in Jakarta based on gender. Because of this perceived fatigue, female participants are increasingly avoiding news regarding COVID-19.
\end{abstract}

Keywords: gender gap; news consumption; news avoidance; news fatigue; pandemic

\begin{abstract}
Abstrak
Di era 'banjir' informasi saat ini, masyarakat berlomba-lomba ingin menjadi yang tercepat mengetahui dan membagikan informasi, terutama yang berkaitan dengan pandemi COVID-19. Terlebih bagi mereka yang tinggal di daerah metropolitan seperti Jakarta (dengan jumlah kasus COVID-19 terbanyak per Januari 2021) yang selalu dituntut untuk up to date. FOMO (Fear of Missing Out), merupakan perasaan cemas atau tidak aman atas kemungkinan kehilangan atau ketinggalan sesuatu. FOMO akan membuat seseorang semakin gencar dalam mengakses informasi yang pada akhirnya dapat berujung pada news fatigue, yaitu kondisi di mana seseorang merasa stres atau kelelahan karena informasi yang berlebihan. Peneliti mencoba melihat bagaimana perbedaan praktik news fatigue di Jakarta berdasarkan gender dalam konteks pandemi. Penelitian ini menggunakan teori Uses and Gratificats 2.0 dengan konsep news fatigue to news avoidance serta konsep gender dan berita. Sebagai riset deskriptif-kualitatif dengan metode studi kasus, peneliti menggunakan teknik pengumpulan data berupa media diary dan wawancara mendalam. Hasil penelitian ini menunjukkan bahwa partisipan perempuan menyikapi pengalaman news fatigue berbeda daripada partisipan laki-laki. Dalam konteks berita COVID-19, partisipan perempuan melaporkan merasa lelah dengan topik tersebut terutama karena kebanyakan beritanya bernada negatif dan diberitakan terus-menerus. Selain itu, faktor pekerjaan dan beban ganda partisipan memainkan peran penting dalam praktik news fatigue di Jakarta berdasarkan gender. Kelelahan yang dirasakan ini mendorong partisipan perempuan untuk menghindari berita tentang COVID-19.
\end{abstract}

Kata kunci: gender gap; konsumsi berita; news avoidance; news fatigue; pandemi

Korespondensi: Michelle Natasya, S.I.Kom., Fakultas Ilmu Komunikasi Universitas Multimedia Nusantara, J1. Scientia Boulevard, Gading Serpong, Tangerang 15227, Email: michelle.natasya1@gmail.com

Menyerahkan: Januari 2021, Diterima: Mei 2021, Terbit: Juli 2021

ISSN: 2549-0559 (cetak), ISSN: 2549-1946 (online), Website: http://jurnal.unpad.ac.id/kajian-jurnalisme 
DOI: $10.24198 / \mathrm{jkj} . v 5 \mathrm{i} 1.31587$

\section{PENDAHULUAN}

Meskipun pandemi COVID-19 sudah berlangsung lebih dari setahun, tidak sedikit dari mereka di Indonesia yang merasa perlu untuk terus memantau perkembangan virus tersebut. Terlebih lagi, berita pandemi ini hampir setiap hari hadir di berbagai media, baik di media daring maupun media sosial. Lalu, karena gempuran informasi ini maka semua orang diharapkan mampu menyaring konten yang dikonsumsinya, tapi sayangnya justru semakin banyak orang yang memilih untuk berhenti mengikuti berita (Palmer \& Toff, 2018). Padahal, dengan berhenti mengikuti berita tentang virus corona justru dapat menurunkan kewaspadaan individu tentang potensi penyebaran virus berbahaya ini.

Di sisi lain, masyarakat berlomba-lomba ingin menjadi yang tercepat mengetahui dan membagikan informasi. Hal yang sama juga dapat terjadi dalam hal konsumsi dan sirkulasi berita tentang virus corona. Terlebih bagi mereka yang tinggal di daerah metropolitan seperti Jakarta yang selalu dituntut untuk up to date dalam banyak hal. Padahal, FOMO dapat memengaruhi pengambilan keputusan dan perilaku seseorang (Abel, Buff, \& Burr, 2016). Perasaan FOMO di tengah kondisi information overload pada akhirnya dapat membuat seseorang berujung pada news fatigue - kondisi di mana seseorang merasa stres atau kelelahan karena informasi yang berlebihan (Poyant, 2016).

Kondisi news fatigue ini juga dimungkinkan oleh sejumlah faktor. Salah satunya adalah persepsi news will find me. Banyak orang yang berpendapat bahwa mereka tidak perlu lagi aktif mencari informasi karena informasi dengan sendirinya mendatangi mereka (Gil de Zúñiga \& Diehl, 2018). Artinya, meskipun mereka tidak secara sengaja mengakses berita soal COVID-19 di media massa, berita yang sama dianggap tetap memiliki kemungkinan untuk muncul di hadapan mereka melalui platform lain seperti media sosial. Hal ini membuat seseorang dapat menemukan sebuah berita atau informasi terkini bahkan ketika mereka belum secara aktif mencarinya. Pengalaman ini disebut incidental news exposure (Tewksbury, Weaver, \& Maddex, 2001). Sehingga, menjadi sulit bagi seseorang untuk sepenuhnya menghindari berita, terlebih lagi terkait dengan isu penting yang sedang hangat dibicarakan oleh masyarakat, misalkan soal COVID-19.

Terkait dengan praktik news fatigue, juga belum banyak penelitian sejenis yang menjelaskan bagaimana praktek news fatigue tersebut terjadi dalam konteks konsumsi berita COVID-19 di Indonesia, terutama jika dilihat dari perspektif gender. Selain itu, pada riset yang dilakukan oleh Toff dan Palmer diketahui bahwa perempuan lebih cenderung menghindari berita daripada pria (Toff \& Palmer, 2019). Kesenjangan gender dalam news avoidance yang diperparah dengan news fatigue ini menimbulkan kekhawatiran karena jika perempuan kurang mengetahui berita, mereka mungkin berada pada posisi yang buruk untuk melakukan advokasi bagi diri mereka sendiri terutama secara politis. Dalam kasus politik, kelelahan terhadap berita atau topik tertentu bisa menjadi ancaman potensial terhadap transisi politik dan proses demokratisasi (Schumann, 2018). Tetapi, belum ada data empiris yang dapat digunakan untuk menjelaskan perilaku masyarakat terkait dengan berita kesehatan dan pandemi. Penelitian kali ini mencoba untuk melihat perbedaan praktik news fatigue berdasarkan gender di Jakarta, mengingat hingga Februari 2021, Jakarta masih menjadi wilayah dengan angka kasus COVID-19 terbanyak di Indonesia (e.g., data terbaru dapat diakses di covid19.go.id). Untuk itu, peneliti mengajukan rumusan masalah yaitu bagaimana konsep gender berperan dalam praktek news fatigue terkait dengan konsumsi berita COVID-19 di masyarakat Jakarta.

Dengan semakin meningkatnya penyebaran virus corona di Indonesia, maka diharapkan masyarakat juga semakin waspada terhadap penularan COVID-19 di lingkungan mereka. Selain itu, mengelola gempuran informasi setiap hari menjadi salah satu tantangan paling mendesak 
di era digital saat ini (Palmer \& Toff, 2018). Dalam konteks berita pandemi COVID-19, audience semakin dibanjiri dengan beragam konten soal virus corona di berbagai platform sehingga menjadi penting untuk memahami bagaimana mereka mengelola informasi yang dikonsumsinya.

Menurut kondisi banjir informasi yang disertai dengan perasaan FOMO, akan membawa seseorang berujung pada news fatigue, yaitu kondisi di mana seseorang merasa stres atau kelelahan karena informasi yang berlebihan (Poyant, 2016). Gottfried (2020) mengemukakan bahwa news fatigue terjadi ketika seseorang merasa ada terlalu banyak berita dan kewalahan karena tidak dapat mengikuti jumlah berita yang ada tadi. Riset tersebut juga menemukan bahwa perempuan cenderung lebih merasa lelah dengan berita daripada laki-laki dengan persentase yaitu $71 \%$ untuk perempuan dan $64 \%$ untuk laki-laki.

Selain itu, banjir informasi dapat membuat seseorang merasa news fatigue dan kemudian akan mengarah pada news avoidance atau penghindaran berita. Fenomena penghindaran berita itu sendiri terjadi di banyak negara. Misalkan saja, hasil survei Digital News Report 2017 yang diterbitkan oleh Reuters Institute, memperlihatkan bahwa antara 6 sampai 57 persen orang di seluruh dunia mengatakan bahwa mereka kadang-kadang atau seringkali menghindari berita (Newman et al., 2017). Data dalam survei tersebut tidak mencakup informasi tentang perilaku masyarakat di Asia Tenggara semacam Indonesia, sehingga tidak ada gambaran konkret terkait fenomena ini, terutama yang dihubungkan dengan praktek news fatigue.

Selain itu, dalam riset yang dilakukan oleh Schumann diketahui bahwa biasanya hanya topik tertentu yang menyebabkan news fatigue, seperti topik yang itu-itu saja muncul di media (Schumann, 2018). Meskipun demikian, riset milik Schumann juga tidak menjelaskan lebih lanjut bagaimana jika topik yang muncul berulang kali tersebut adalah isu yang penting seperti tentang pandemi COVID-19, fenomena yang terjadi secara global. Meskipun berita tentang virus corona sering muncul di berbagai media, baik media massa tradisional maupun media sosial, bukan berarti kita dapat mengabaikan nilai penting dari berita tersebut untuk kondisi pandemi saat ini.

Sejumlah penelitian terdahulu menjelaskan bahwa laki-laki dan perempuan memiliki perbedaan yang sangat signifikan dalam menyikapi berita, menginterpretasi informasi, dan memahami keseluruhan informasi (Benesch, 2012; Selva \& And1, 2020). Selain itu, Toff dan Palmer menemukan baik dalam konteks penelitian kuantitatif maupun kualitatif, keduanya menunjukkan bahwa laki-laki dan perempuan memiliki cara pendekatan yang berbeda terhadap berita (Toff \& Palmer, 2019). Dalam riset yang lain, dijelaskan bahwa perempuan mengonsumsi berita lebih karena dorongan untuk mencari informasi (Lee, 2013). Selain itu, laki-laki lebih tertarik pada berita politik sedangkan perempuan lebih suka berita pendidikan dan kesehatan (Selva \& And1, 2020).

Isu yang lain adalah soal ketimpangan struktural. Laki-laki cenderung bekerja di luar rumah, sedangkan perempuan cenderung bekerja di dalam rumah. Hal ini menyebabkan akses terhadap berita lebih tinggi di kalangan laki-laki dibandingkan perempuan. Sebagai contoh, perempuan dianggap memiliki waktu luang lebih banyak daripada laki-laki. Padahal, kalaupun perempuan tinggal di rumah (Ibu Rumah Tangga), tanggung jawab pengasuhan anak biasanya menjadi tanggung jawab perempuan, sama halnya dengan pekerjaan rumah tangga (Altintas \& Sullivan, 2016), sehingga waktu mereka untuk mengakses berita juga terbatas (Toff \& Palmer, 2019). Lebih dari itu, perbedaan gender dalam konsumsi berita sangat besar di antara (kedua) orang tua yang bekerja dan memiliki anak, di mana perempuan merasa tanggung jawab mereka lebih besar sehingga berdampak pada berkurangnya konsumsi berita (Benesch, 2012).

Sejumlah penelitian terdahulu di atas umumnya dilakukan dalam konteks ekosistem 
media di negara Barat. Belum tentu hal tersebut secara otomatis dapat dibuktikan pada konteks yang berbeda di negara Asia seperti Indonesia. Oleh karena itu, penelitian ini dilakukan guna mengisi research gaps dengan memaparkan data empiris tentang bagaimana dan mengapa peran gender berperan dalam praktik news fatigue di masyarakat Indonesia, khususnya Jakarta, dalam hal konsumsi berita terkait COVID-19.

\section{METODE}

Penelitian ini merupakan penelitian kualitatif yang bersifat deskriptif yang mencoba untuk menjelaskan secara detail sekaligus menjawab pertanyaan bagaimana perbedaan antara lakilaki dan perempuan di Jakarta dalam praktik news fatigue terkait berita COVID-19. Penelitian ini menggunakan metode single-case case study, di mana metode penelitian studi kasus lebih tepat dalam menjawab pertanyaan 'how' dan 'why' (Yin, 2018). Menurutnya, peneliti juga biasanya fokus pada fenomena-fenomena yang sedang terjadi di dunia nyata. Dalam konteks ini, peneliti berupaya melihat kasus konsumsi berita COVID-19 di Jakarta dengan sudut pandang gender dan news fatigue menggunakan media diary dan wawancara mendalam sebagai teknik pengumpulan data.

Peneliti merekrut partisipan menggunakan teknik snowball sampling, di mana peneliti meminta partisipan pertama, yang dipilih melalui convenience sampling (bagian populasi yang tersedia untuk peneliti, dipilih dengan metode open recruitment di media sosial), untuk merekomendasikan setidaknya satu partisipan lain dengan pandangan atau situasi yang sama dengan dirinya untuk mengambil bagian dalam penelitian. Selanjutnya, partisipan menghubungkan peneliti pada partisipan lainnya, dengan begitu partisipan terus bertambah. Pemilihan partisipan didasari oleh beberapa kriteria keterwakilan sebagai berikut: (1) gender: laki-laki dan perempuan; (2) generasi X (lahir antara tahun 1965-1980) dan generasi Y (lahir antara tahun 1981-1996); dan (3) pekerja formal dan pekerja informal, mengingat dari riset sebelumnya dijelaskan bahwa generasi/usia dan jenis pekerjaan dapat menjelaskan variasi dalam konsumsi berita (Nelissen, Konig, \& Karsten, 2008; Taneja, Wu, \& Edgerly, 2018). Karena penelitian ini membahas mengenai news fatigue di Jakarta, maka setiap partisipan harus merupakan individu yang masuk dalam kategori frequent readers atau pengguna/pembaca media secara rutin (Fortunati, Deuze, \& de Luca, 2014) dan berdomisili di Jakarta, serta mereka yang setuju untuk berpartisipasi dalam penelitian diberikan informed consent.

Tabel 1. Partisipan Penelitian

\begin{tabular}{|c|l|l|l|}
\hline No & Nama Panggilan & \multicolumn{1}{c|}{ Kategori Generasi } & \multicolumn{1}{c|}{ Kategori Pekerjaan } \\
\hline 1 & Stella (perempuan) & Gen X (lahir 1976) & Informal (pedagang daring) \\
\hline 2 & Lila (perempuan) & Gen X (lahir 1973) & Formal (pengajar bahasa) \\
\hline 3 & Ervira (perempuan) & Gen Y (lahir 1989) & Informal (freelancer) \\
\hline 4 & Emira (perempuan) & Gen Y (lahir 1983) & Formal (karyawan bank) \\
\hline 5 & Welia (laki-laki) & Gen X (lahir 1971) & Informal (pedagang keramik antik) \\
\hline 6 & Arya (laki-laki) & Gen X (lahir 1973) & Formal (karyawan swasta) \\
\hline 7 & Wendy (laki-laki) & Gen Y (lahir 1987) & Informal (wiraswasta) \\
\hline 8 & Henri (laki-laki) & Gen Y (lahir 1983) & Formal (dokter gigi) \\
\hline
\end{tabular}

Sumber: diolah oleh peneliti

Kepada partisipan yang terpilih, peneliti meminta mereka untuk membuat media diary berupa buku harian yang berisikan: aktivitas sehari-hari atau kesibukan partisipan, kebiasaan konsumsi berita (kapan, berapa lama, berita apa saja yang diakses, berita apa saja yang 
dihindari, dan sumber berita), alasan mengakses berita, perasaan/pemikiran apa yang timbul saat terpapar dan/atau mengonsumsi banyaknya berita, refleksi kenapa perasaan/pemikiran tersebut muncul, dan keputusan apa yang dilakukan selanjutnya setelah perasaan/pemikiran tersebut muncul. Mereka mengisi media diary ini setiap hari melalui Google Docs selama dua minggu. Keuntungan dari metode media diary ini yaitu data dikumpulkan dalam periode waktu tertentu sehingga memungkinkan respon lebih kaya dan reflektif (Gulyas, O'Hara, \& Eilenberg, 2019). Selain itu, karena penelitian ini dilakukan saat diberlakukan Pembatasan Sosial Berskala Besar (PSBB) di Jakarta dan sekitarnya, maka media diary digunakan sebagai alternatif dari teknik pengumpulan data observasi lapangan (field observation).

Kemudian, peneliti melakukan wawancara mendalam (in-depth interview) secara daring setelah mengkaji media diary setiap partisipan guna mendapatkan data yang lebih rinci mengenai pandangan partisipan sekaligus klarifikasi dan memastikan tidak ada data relevan lainnya yang terlewat. Untuk meminimalisir perbedaan pengetahuan mengenai berita, peneliti memberikan gambaran terlebih dahulu pada partisipan mengenai apa yang dimaksud dengan berita dalam penelitian ini. Data media diary maupun data wawancara mendalam dalam penelitian ini dikumpulkan selama kurun waktu dari 6 April 2020 sampai 25 April 2020.

\section{HASIL DAN PEMBAHASAN}

\section{Gender, Pola Konsumsi Berita di Era COVID-19 dan FOMO}

Peneliti mengidentifikasi beberapa variasi tentang relasi peran gender dan pola konsumsi berita partisipan di era COVID-19 ini. Temuan ini menyangkut beberapa hal yang saling terkait, yaitu: kebiasaan konsumsi berita setiap gender, alasan mengakses atau tidaknya berita bagi setiap gender, pengaruh kesibukan sehari-hari terhadap batasan konsumsi berita setiap gender, seberapa penting mengikuti berita bagi setiap gender, dan ketertarikan setiap gender dalam mengikuti berita politik dan ekonomi yang sering dianggap sebagai ranah maskulin.

Tabel 2. Deskripsi Konsumsi Berita Partisipan Penelitian

\begin{tabular}{|c|l|l|l|}
\hline No & \multicolumn{1}{|c|}{ Nama } & Lama Akses Berita & Waktu Akses Berita \\
\hline 1 & Stella (perempuan) & $\begin{array}{l}\text { Akumulasi baca berita } \\
\text { daring kurang lebih 2 jam } \\
\text { per hari. }\end{array}$ & $\begin{array}{l}\text { Lebih sering baca berita pagi hari setelah } \\
\text { bangun tidur. Saat siang lebih suka } \\
\text { mencari berita lucu karena sudah jenuh } \\
\text { dan lelah. }\end{array}$ \\
\hline 2 & Lila (perempuan) & $\begin{array}{l}\text { Akumulasi baca berita } \\
\text { daring kurang lebih 3 jam } \\
\text { per hari. }\end{array}$ & $\begin{array}{l}\text { Pagi hari sambil menunggu jam kerja } \\
\text { selama 1 jam baca Kompas.id section } \\
\text { internasional. Siang atau sore hari setelah } \\
\text { pulang kerja akses berita dari Facebook. } \\
\text { Malam hari setelah seluruh kegiatan } \\
\text { selesai buka Facebook dan terpapar } \\
\text { berita daring. }\end{array}$ \\
\hline 3 & Ervira (perempuan) & $\begin{array}{l}\text { Akumulasi buka portal } \\
\text { media daring 5 kali dalam } \\
\text { sehari dengan durasi 20-30 } \\
\text { menit. }\end{array}$ & $\begin{array}{l}\text { Bangun tidur langsung akses berita } \\
\text { dengan buka portal media daring. Pada } \\
\text { siang hari browsing berita di sela-sela } \\
\text { jam kerja atau sambil bekerja. Pada } \\
\text { malam hari browsing berita sebelum } \\
\text { tidur. }\end{array}$ \\
\hline
\end{tabular}




\begin{tabular}{|c|c|c|c|}
\hline 4 & Emira (perempuan) & $\begin{array}{l}\text { Akumulasi baca berita } \\
\text { daring kurang lebih } 2 \text { jam } \\
\text { per hari. }\end{array}$ & $\begin{array}{l}\text { Bangun tidur langsung baca atau dengar } \\
\text { berita daring (audio). Pada siang hari, } \\
\text { baca berita di sela-sela jam kerja (istirahat } \\
\text { makan siang atau sebelum ketemu klien) } \\
\text { selama } 10-15 \text { menit karena tuntutan } \\
\text { profesi. pada malam hari sebelum tidur, } \\
\text { baca berita dari notifikasi pop up media } \\
\text { daring. }\end{array}$ \\
\hline 5 & Welia (laki-laki) & $\begin{array}{l}\text { Akumulasi baca berita } \\
\text { kurang lebih } 2 \text { jam per hari. }\end{array}$ & $\begin{array}{l}\text { Bangun tidur langsung sekilas baca } \\
\text { berita daring. Siang hari buka Facebook } \\
\text { di sela-sela waktu bekerja dan terpapar } \\
\text { berita daring. Waktu kosong di malam } \\
\text { hari dihabiskan dengan baca berita } \\
\text { daring dari Facebook atau nonton TV. }\end{array}$ \\
\hline 6 & Arya (laki-laki) & $\begin{array}{l}\text { Akumulasi konsumsi berita } \\
\text { kurang lebih } 3 \text { jam per hari. }\end{array}$ & $\begin{array}{l}\text { Pagi hari sebelum kerja nonton berita di } \\
\text { TV atau baca media daring. Pada siang } \\
\text { hari, baca berita daring di sela-sela jam } \\
\text { kerja selama } 30 \text { menit. Di perjalanan } \\
\text { pulang kalau macet buka portal berita } \\
\text { daring atau dengar berita radio. Lanjut } \\
\text { pada sore hari kerja sambil baca berita } \\
\text { daring. Malam hari setelah kegiatan } \\
\text { selesai lanjut nonton TV atau baca berita } \\
\text { daring (buka portal berita/media sosial). }\end{array}$ \\
\hline 7 & Wendy (laki-laki) & $\begin{array}{l}\text { Akumulasi buka portal } \\
\text { media daring } 2-5 \text { kali } \\
\text { dalam sehari. Akumulasi } \\
\text { kurang lebih } 2 \text { jam per hari. }\end{array}$ & $\begin{array}{l}\text { Tidak ada waktu yang spesifik. Buka } \\
\text { media daring ketika ingin update berita. } \\
\text { Biasanya pagi atau siang hari buka } \\
\text { portal media daring setelah bangun tidur } \\
\text { atau sambil bekerja. Baca berita daring } \\
\text { saat sore atau malam hari ketika waktu } \\
\text { senggang atau sebelum tidur. }\end{array}$ \\
\hline 8 & Henri (laki-laki) & $\begin{array}{l}\text { Akumulasi baca berita } \\
\text { kurang lebih } 2 \text { jam per hari. }\end{array}$ & $\begin{array}{l}\text { Jika tidak sedang praktik pagi hari } \\
\text { biasanya baca berita daring. Sore hari } \\
\text { baca berita di sela-sela waktu bekerja } \\
\text { jika waktu sedikit longgar. Jika seharian } \\
\text { tidak bisa akses berita maka malam hari } \\
\text { akses berita. }\end{array}$ \\
\hline
\end{tabular}

Sumber: diolah oleh peneliti

Seluruh partisipan menggunakan media daring untuk mengonsumsi berita, terutama karena dapat diakses di mana pun dan kapan pun, serta memungkinkan mereka untuk bekerja sambil terus update dengan informasi. Meskipun begitu, mereka memiliki cara dan media pilihan yang berbeda dalam mengakses berita. Dua dari empat partisipan laki-laki mengatakan bahwa mereka lebih sering mencari berita sendiri dengan membuka langsung portal atau aplikasi media daring. Sedangkan para partisipan perempuan mengaku lebih banyak yang membaca berita karena mengalami incidental news exposure atau terpapar secara tidak sengaja.

Dalam pengakuan Emira, ia lebih sering terpapar berita dari notifikasi aplikasi media daring yang ia unduh, secara tidak sengaja ketika sedang berselancar di media sosial, atau sesekali dikirimi link berita dari grup WhatsApp. Ia juga mengatakan bahwa berita yang biasanya ia buka dan baca adalah berita yang judulnya menarik. Namun, jika ia mendapati judul berita yang tidak sesuai dengan isi berita, maka berita tersebut akan ia skip. Hal yang sama juga terjadi dengan Stella.

Sementara itu, Lila, meskipun setiap pagi ia dengan sengaja mencari berita sendiri dengan membuka situs berita Kompas.id, ia mengaku (saat sore atau malam hari) membuka media sosial Facebook dan terpapar dengan berita secara tidak sengaja. Lebih lanjut ia mengatakan 
bahwa Facebook memiliki algoritma tersendiri yang dapat menilai berita apa yang kira-kira sesuai dengan preferensinya sehingga merekomendasikan banyak berita yang menurutnya menarik untuk dibaca. Oleh sebab itu, ia akhirnya sering membuka media sosial Facebook untuk mencari berita.

Terkait jenis berita yang disuka dan tidak disuka bagi setiap kelompok gender, peneliti menemukan bahwa partisipan laki-laki lebih terbuka dalam hal membaca berita. Kebanyakan dari mereka mengatakan bahwa mereka menyukai dan membaca segala jenis berita. Seperti yang dikatakan oleh Welia, "... saya termasuk pemakan segala jenis berita, dalam arti berita yang menambah wawasan...” (Welia, Wawancara. 23 April 2020). Mereka juga tidak menyukai berita yang bias, provokatif, tidak berimbang, menggiring opini, tidak berdasarkan fakta, dan tidak akurat.

Kebanyakan partisipan perempuan mengatakan bahwa berita yang mereka sukai adalah berita-berita dengan tone positif. Mereka cenderung tidak suka dan menghindari berita-berita negatif. Seperti yang dikatakan oleh Ervira, ia menyukai berita yang menyejukkan hati. Ervira juga menghindari berita yang membuat stres. Menurutnya, “... karena 'kan pekerjaan (saya) juga emotionally drained off. Jadi kalau baca berita negatif otomatis juga tambah capek" (Emira, Wawancara. 22 April 2020). Untuk itu, mereka mengaku tidak terlalu suka topik politik dan olahraga serta lebih menyukai berita tentang entertainment.

Peneliti juga menemukan bahwa partisipan baik laki-laki maupun perempuan merasa tidak nyaman ketika tidak mengikuti berita. Perasaan ini kerap kali muncul karena adanya rasa penasaran dengan keadaan sekitar sehingga ingin selalu mengakses berita, perasaan yang tidak enak, dan pada tahap ekstrim merasa gelisah atau cemas ketika tidak mengikuti berita. Salah satu partisipan laki-laki, Welia, bahkan sudah sampai berada di tahap ekstrim yaitu merasa gelisah ketika beberapa saat belum membuka media daring untuk membaca berita. Ia mengaku kecanduan membaca berita. Baginya, membaca berita merupakan bagian dari gaya hidup dan sebuah kebutuhan. Menurutnya,

“... jadi gelisah kalau beberapa saat kita belum membuka apps (media daring) seperti ini, jadi saya rasa sudah menjadi satu gaya hidup, mungkin juga kebutuhan. (...) saya itu menjadi (yang) orang bilang kecanduan... hmm... sesuatu yang harus ada, kalau gak, kita jadi nervous. Jadi setuju sekali bahwa ini (baca berita) adalah sesuatu ketergantungan." (Welia, Wawancara. 23 April 2020)

Tak jauh berbeda, partisipan perempuan yaitu Ervira juga mengatakan bahwa ia takut ketinggalan berita. Terlebih untuk berita yang masuk dalam kategori penting baginya untuk diketahui seperti berita tentang virus corona. Ervira menjelaskan,

"Tapi kalau dalam situasi kayak gini sekarang ya mungkin lumayan kali ya. Tapi kalau in general sih kalau kondisi lagi aman-aman aja ya gak terlalu. Jadi sebenernya tergantung situasinya juga. (Kalau situasi COVID-19) penasaran sih kayak, aduh update sekarang kayak gimana gitu. Apa makin parah atau membaik? Gitu sih." (Ervira, Wawancara. 21 April 2020)

Lila menuturkan tentang kecemasannya saat tidak dapat mengakses berita di era pandemi COVID-19. Lila lanjut bercerita,

"Ada waktu itu 2 atau 3 hari luar biasa di lockdown dimana-mana waktu saya pergi travelling itu ke Holly Land di Israel dan Mesir. (...) itu perasaan cemas luar biasa, sampe gak ngikutin berita apapun lagi, dalam artian udah gak bisa. (...) terus jadi begitu banyak berita-berita jadi gak enak, terus tumpuk-tumpuk gitu, itu saya kehilangan berita 3 hari. Saya merasa gelisah gitu loh, kok saya gak baca-baca begitu, tapi mau buka pun," saya gak bisa karena waktu sibuk saat itu dan tidak bisa konsentrasi, ada kegelisahan." (Lila, Wawancara. 25 April 2020) 


\section{Gender dan Ragam Faktor Pendorong News Fatigue}

Kelelahan terhadap berita yang paling banyak muncul karena para informan merasa banyaknya berita yang mereka temui umumnya bernada negatif, banyaknya berita dengan informasi yang diulang-ulang, dan banyaknya jumlah berita yang ada. Hal ini disebabkan pengumpulan data dilakukan saat pemberlakuan pembatasan sosial selama pandemi COVID-19. Selain itu, berita yang muncul kebanyakan bernada negatif serta topik COVID-19 menjadi bahasan utama setiap kategori berita dalam jangka waktu yang cukup lama.

Meskipun begitu, hasil penelitian menggambarkan bahwa ada kecenderungan partisipan laki-laki tidak merasa lelah ataupun jenuh dengan berita bernada negatif. Tiga dari empat partisipan laki-laki mengatakan bahwa mereka merasa biasa saja meskipun membaca banyak berita negatif di tengah pandemi saat ini. Wendy mengatakan ia tidak jenuh ataupun lelah dengan berita COVID-19 meskipun kebanyakan beritanya bernada negatif. Menurutnya, “... selama berita negatif itu memang benar dan faktual gak ada masalah, tetap dibaca. Perasaan cenderung biasa aja, mengarah tertarik.” (Wendy, Wawancara. 21 April 2020)

Welia mengaku masih giat mengikuti berita COVID-19 yang kebanyakan bernada negatif meski seringkali membuatnya tidak tenang. Menurutnya, baca berita Covid saja tidak langsung membuatnya khawatir. Perasaan khawatir muncul karena secara aktual berhadapan dengan COVID-19, bukan karena membaca beritanya.

Sementara itu, seluruh partisipan perempuan merasa jenuh dan lelah dengan berita bernada negatif, terlebih jika jumlahnya banyak. Menurut Ervira, ia sempat stres mengikuti berita COVID-19 karena seringkali membuat perasaannya jadi negatif. Ia menuliskan hal tersebut di dalam media diary, “... terekspos dengan berita yang berat bertubi-tubi memang terkadang melelahkan ...” (Ervira, Media Diary. 9 April 2020). Ervira mengatakan bahwa pada awalnya ia sempat merasa stres, takut, dan lelah mengikuti berita COVID-19, namun lama kelamaan jadi semakin terbiasa bahkan cenderung jenuh mengikuti berita tersebut.

Stella juga mengakui bahwa berita COVID-19 seringkali membuatnya takut, stres, dan membawa perasaan negatif. Ia mengatakan,

“... karena tiap hari tuh aku dibom terus sama (berita) corona gitu kan. Aduh ini udah bikin stres nih, kita ekonominya jatuh, diinfo sama tiap hari ada orang mati lah, tiap hari ada orang sakit lah, ada pasien kabur lah, gitu kan, takut gitu loh. (...) Iya capek. (...) itu dibombardir terus gitu, dihajar terus sama tone beritanya negatif, hawanya tuh gak enak gitu loh.” (Stella, Wawancara. 22 April 2020)

Lila mengatakan bahwa membaca berita negatif membuat perasaannya jadi panik, lelah secara mental, khawatir dan sempat merasa putus asa. Bahkan berita COVID-19 yang kebanyakan negatif membuatnya sulit tidur. Membaca berita ekonomi pun saat ini (di tengah pandemi) membuatnya cemas dan lelah. Hal ini karena berita ekonomi yang diberitakan adalah ekonomi dunia yang ikut memburuk.

Berita COVID-19 yang dibahas terus-menerus dalam jangka waktu yang cukup lama menurut Ervira juga membuatnya lelah. Dalam cerita Ervira,

“...karena belakangan beritanya kan related ya semuanya ke Covid. Jadi semuanya tuh related ke COVID-19. Jadi kadang tuh kayak haduh...ada yang lain gak sih? Atau ada berita yang gak ada Covidnya ini gak sih? Tapi nyatanya semua related ke Covid deh. Jadi jenuh juga sih dengerinnya Covid lagi gak kelar-kelar, lockdown juga." (Ervira, Wawancara. 21 April 2020)

Lain halnya dengan Welia, berita yang membuatnya jenuh bukanlah berita dengan topik sama yang dibahas terus-menerus, melainkan berita dengan informasi yang repetitif atau diulang-ulang. Jadi bukan soal topik virus corona yang hampir tiap hari muncul di media massa, melainkan tentang berita yang sama yang diulang-ulang. Stella juga mengeluhkan soal 
berita yang cenderung repetitive tersebut. Dalam media diary, Stella menuliskan,

"...sudah sangat jenuh dengan pemberitaan (Covid) yang massive dan isinya itu-itu saja. (...) Aku juga baca berita tentang PSBB di DKI, tapi nggak terlalu interested lama-lama bosan juga. Udah tau harus social distancing, pakai masker, hand sanitizer, gitu lagi, gitu lagi." (Media Diary, 11 April)

Lila juga mengatakan bahwa ia merasa jenuh dengan berita yang hanya menyampaikan informasi sama. Ia mengaku jenuh dengan berita kesehatan soal COVID-19 karena dibahas terus-menerus. Terlebih berita kesehatan bukan berita utama pilihannya. Lebih lanjut Lila bercerita,

“... (berita kesehatan) bukan nomor satu .....lalu apapun yang orang ngomong, akan ditelen gitu loh. Kita harus begini, kita harus begitu, diikutin, vitamin ini, vitamin itu...... Letih? lya......terlalu over gitu untuk dibangkitkan di dalam satu topik artikel gitu. Sehat terus-terusan. Lu coba aja baca terus-terusan, pasti lama-lama muak gitu loh. Karena saya mengikuti sejak awal...akhirnya bosen gitu, bosen." (Lila, Wawancara. 25 April 2020)

Sementara itu, jumlah berita yang banyak (massive) soal COVID-19 ternyata tidak sepenuhnya dikeluhkan sebagai faktor yang mendorong news fatigue, terutama bagi partisipan laki-laki. Tiga dari empat partisipan laki-laki mengatakan mereka tidak merasa lelah ataupun jenuh dengan banyaknya jumlah berita. Bahkan beberapa mengatakan bahwa mereka merasa senang mengikuti banyaknya jumlah berita yang ada. Misalkan saja Wendy. Ia tidak merasa terbebani dengan banyaknya jumlah berita karena sudah terbiasa serta tidak merasakan efek negatif dari membaca banyak berita. Senada dengan Wendy, Arya juga mengatakan semakin banyak berita justru semakin bagus. Ia mengaku sangat suka membaca banyak berita daring.

Sama halnya dengan Welia. Banyaknya jumlah berita tidak membuatnya jenuh ataupun lelah. Menurutnya, tidak ada alasan baginya untuk merasa jenuh ataupun lelah dengan banyaknya jumlah berita. Welia bahkan merasa diuntungkan dengan kehadiran media daring yang cepat dalam update berita baru setiap saat sehingga ia dapat terus memantau perkembangan isu COVID-19.

Sementara itu, dua dari empat partisipan perempuan mengatakan mereka justru jenuh dan lelah dengan banyaknya jumlah berita. Dua perempuan lainnya mengatakan bahwa mereka tidak merasa jenuh maupun lelah dengan banyaknya jumlah berita saat ini. Lila mengaku tidak masalah dengan banyaknya jumlah berita asalkan bahasan dan topik beritanya tidak itu-itu saja. Menurut Ervira, membaca banyak berita dalam sehari biasa saja baginya. Membaca banyak berita negatif lah yang menurutnya melelahkan.

Bagi partisipan laki-laki seperti Wendy, membaca banyak berita negatif tidak membuatnya lelah ataupun jenuh asalkan faktual dan benar. Wendy juga mengaku tidak merasa khawatir/ cemas membaca banyak berita negatif di tengah kondisi pandemi. Ia mengatakan ketakutan dan keresahan tidak akan membawa manfaat dan hanya membuat dirinya tidak bisa berpikir jernih. Juga bagi Arya, membaca berita negatif soal COVID-19 dapat membuatnya semakin mawas diri dan meningkatkan awareness. Hal ini terjadi karena semakin banyak berita COVID-19 yang ia baca, ia jadi lebih berhati-hati. Dengan banyak membaca berita tentang corona, Arya mengaku jadi semakin tahu perkembangan virus ini dan kebijakan pemerintah terkait pandemi, serta membantunya dalam membedakan berita hoax dan benar.

Sejumlah partisipan juga memaparkan tentang strategi mereka dalam menghadapi news fatigue soal COVID-19. Lila misalkan, hanya mengakses berita terkait COVID-19 yang membahas topik ini dengan sudut pandang yang berbeda dari kebanyakan berita, serta berhenti mengikuti berita yang informasinya itu-itu saja dan terlalu complicated. Selain itu, ia mengembangkan strategi detoks berita, yaitu dengan cara membaca berita COVID-19 dengan 
seimbang: membaca berita negatif COVID-19 terlebih dahulu lalu menjadikan berita positif sebagai penutup.

Emira juga tidak dapat menghindari sepenuhnya berita COVID-19. Alasannya, karena walaupun berita soal virus corona seringkali membuat khawatir tapi tetap harus tahu perkembangannya. Terlebih menurutnya tidak ada berita lain selain COVID-19, jadi mau tidak mau tetap diakses. Ia menuturkan,

"Mungkin harus mulai kurangin membaca tentang update kondisi pandemic dan resesi saat ini, tapi karena sudah terbiasa, jadi takut kudet. Jadi saya akan tetap baca sih. Apalagi pop up notif itu judulnya suka bikin penasaran." (Media Diary. 8 April 2020)

Lebih lanjut, Emira mengatakan bahwa ia merasa wajib mengikuti berita agar tahu kondisi yang terjadi. Jika sama sekali tidak mengikuti berita, ia seketika merasa bodoh karena tidak memiliki informasi yang penting. Selain itu, pekerjaannya sebagai marketing di sebuah bank swasta juga mengharuskannya untuk update berita.

Selain itu, alasan Stella masih mengikuti berita COVID-19 adalah karena berita ini menentukan hidup orang banyak. Ia tetap mengakses berita soal virus corona meskipun harus memilah informasi, karena sebagai pegiat media sosial ia ingin jadi yang pertama untuk melemparkan berita atau isu. Stella juga masih mengikuti beberapa berita COVID-19 meskipun sepintas untuk sekadar tahu perkembangan informasi. Ia mengatakan tidak bisa sepenuhnya menghindari berita karena topik berita COVID-19 banyak yang dikemas dalam format human interest. Stella sendiri sangat menyukai berita yang mengangkat isu human interest.

\section{Implikasi Teoritis terkait Gender dan Kelelahan Berita COVID-19}

Penelitian ini berfokus pada perbedaan antara laki-laki dan perempuan dalam praktek news fatigue yang dikaitkan dengan konsumsi berita di masa pandemi COVID-19 di Indonesia. Setidaknya ada dua hal penting yang ditemukan dalam riset ini terkait dengan masalah penelitian, yaitu (a) tentang pola konsumsi berita pada dua kategori gender dalam hal akses berita COVID-19; (b) FOMO yang muncul terkait dengan berita COVID-19; (c) bagaimana mereka merasakan news fatigue terkait dengan berita yang mereka konsumsi tersebut.

Berdasarkan temuan peneliti, partisipan perempuan cenderung menggunakan media dengan motif ritual (kebiasaan/rutinitas) serta mereka terpapar berita secara tidak sengaja atau mengalami incidental news exposure. Artinya, mereka lebih terbuka terhadap paparan berita secara tidak sengaja dari link di grup WhatsApp, berita yang terintegrasi, notifikasi aplikasi media daring yang diikuti, postingan teman, atau postingan media daring ketika berselancar di media sosial. Di sisi lain, partisipan laki-laki cenderung melaporkan bahwa mereka secara sadar langsung membuka portal media daring untuk mendapatkan berita.

Laki-laki dan perempuan juga cenderung berbeda dalam preferensi jenis atau kategori berita. Audiens laki-laki cenderung lebih terbuka dalam hal konsumsi berita serta menyukai segala jenis berita, terutama berita politik. Partisipan perempuan lebih menyukai berita yang menyejukkan hati, inspirasional, menghibur, dan tidak mainstream dan cenderung menyukai kategori berita seperti entertainment, human interest, profil, dan gaya hidup.Temuan ini serupa dengan riset yang dilakukan oleh Benesch (2012) maupun Selva dan And1 (2020) bahwa lakilaki dan perempuan memiliki cara pendekatan yang berbeda terhadap berita.

Peneliti menemukan partisipan perempuan lebih pemilih soal konsumsi berita. Mereka tidak menyukai kategori berita yang bernada negatif karena dianggap melelahkan, membuat cemas, dan khawatir. Terlebih bagi partisipan perempuan yang pekerjaannya juga melelahkan secara emosional. Mereka lebih suka berita positif yang membangun. Temuan ini senada dengan paparan penelitian Schrøder dan Blach-Orsten yang menemukan bahwa perempuan lebih 
cenderung menginginkan berita yang disajikan dengan cara yang menghibur (Schrøder, 2016). Meskipun umumnya partisipan menghindari berita dengan tone negatif, mereka tidak dapat sepenuhnya menghindari berita-berita ini. Mereka juga tidak menyukai dan menghindari berita olahraga, politik, dan ekonomi. Alasannya, berita-berita ini sulit dipahami, membosankan, bahasannya terlalu rumit, dan seringkali membuat khawatir, senada dengan temuan Toff dan Palmer (Toff \& Palmer, 2019). Mereka mengatakan bahwa sama seperti politik, pertimbangan bahwa berita merupakan ranah maskulin untuk pria juga terjadi dalam hal konsumsi berita.

Namun dalam penelitian ini, apa yang dikatakan Toff dan Palmer tersebut tidak terjadi pada kategori berita secara keseluruhan (Toff \& Palmer, 2019), terutama jika dikaitkan dengan konsumsi berita COVID-19. Perlu digarisbawahi bahwa meskipun partisipan perempuan ini banyak yang menghindari berita-berita tersebut, mereka mengaku tidak dapat sepenuhnya menghindar. Mereka mengaku masih membaca berita politik dan ekonomi yang hot issue dan memiliki dampak langsung bagi mereka, terlebih berita tentang virus corona yang dikonsumsi secara rutin oleh mereka.

Salah satu isu yang juga muncul dalam perbedaan konsumsi berita berbasis gender adalah persoalan ketimpangan struktural. Hasil penelitian ini mengungkapkan bahwa secara umum partisipan tidak merasa kesibukan sehari-hari membatasi konsumsi berita mereka. Namun, satu partisipan laki-laki dan satu partisipan perempuan melaporkan bahwa waktu konsumsi berita mereka terbatas. Hal ini terjadi karena beberapa faktor seperti jenis pekerjaan dan beban ganda partisipan yang harus bekerja sekaligus mengurus anak-anak. Temuan ini sesuai dengan yang dikatakan Toff dan Palmer bahwa waktu adalah salah satu faktor yang membatasi pola konsumsi berita (Toff \& Palmer, 2019). Partisipan laki-laki yang melaporkan keterbatasan konsumsi berita karena kesibukan sehari-hari adalah Henri yang bekerja sebagai dokter gigi. Selain itu, partisipan perempuan yang melaporkan hal ini adalah Emira, pegawai marketing bank swasta sekaligus memiliki anak. Karena harus bekerja sekaligus mengurus anak-anak yang masih kecil ia mengatakan bahwa konsumsi beritanya seringkali terbatas dan harus membagi waktu.

Temuan ini mendukung hasil riset Benesch yang memperlihatkan bahwa perbedaan gender sangat besar di antara orang yang bekerja dan memiliki anak-anak, terutama audiens perempuan (Benesch, 2012). Akan tetapi, ia menambahkan bahwa pembagian kerja dalam rumah tangga dan peran gender yang lebih umum tampaknya juga memainkan peranan penting. Misalkan dalam riset kali ini, partisipan perempuan bernama Stella tidak merasa kesibukannya membatasi konsumsi beritanya meskipun ia bekerja dan memiliki tiga orang anak. Hal ini terjadi karena ketiganya sudah besar dan tidak perlu diurus/diawasi secara lebih seperti yang terjadi pada partisipan Emira.

Benesch menjelaskan pula bahwa karena kendala waktu yang disebabkan oleh beban ganda ini, perempuan akhirnya memilih untuk menghindari berita (Benesch, 2012). Namun berdasarkan hasil riset dalam penelitian kali ini, ditemukan juga faktor kehadiran media daring membawa peranan penting. Meskipun beberapa partisipan mengakui bahwa kesibukan membatasi konsumsi berita mereka, mereka tidak menghindari berita dan tetap dapat membaca berita sambil bekerja karena kepraktisan media daring. Hal ini membuat mereka tidak sepenuhnya hilang akses terhadap berita COVID-19 karena kesibukan sehari-hari.

Selain itu, baik partisipan laki-laki maupun perempuan sama-sama memiliki rasa takut tertinggal berita soal COVID-19. Perasaan yang seringkali muncul yaitu penasaran, cemas ketika tidak mengikuti berita, dan merasa seperti ada yang kurang atau kehilangan. Hal ini menunjukkan bahwa partisipan laki-laki dan perempuan sama dalam praktik FOMO. Penelitian oleh Abel et al. (2016) soal FOMO juga sejalan dengan temuan dalam riset ini. Baik partisipan 
laki-laki maupun perempuan yang melaporkan FOMO terhadap berita juga melaporkan bahwa mereka jadi semakin gencar mengakses berita. Bahkan beberapa dari mereka mengaku bahwa mereka kecanduan media daring sehingga ingin terus mengakses berita.

Temuan lain dari riset ini yaitu terkait dengan kelelahan terhadap berita dan keputusan yang diambil selanjutnya berdasarkan gender mereka masing-masing. Poyant (2016) sebelumnya menjelaskan bahwa FOMO pada nantinya dapat mendorong terjadinya news fatigue. Temuan dalam penelitian ini mengungkapkan partisipan perempuan yang merasa FOMO terhadap berita soal COVID-19 cenderung melaporkan kondisi news fatigue daripada partisipan lakilaki. Dalam konteks tertentu mereka bahkan mencoba menghindari berita tentang virus corona. Hasil temuan ini serupa dengan riset Gottfried (2020) yang menjelaskan perempuan cenderung lebih merasa lelah dengan berita daripada pria. Dalam penelitian ini sejumlah partisipan perempuan mengatakan bahwa mereka merasa lelah dengan banyaknya berita COVID-19. Sementara itu, pada umumnya laki-laki mengatakan bahwa banyaknya berita tidak membuat mereka lelah, bahkan cenderung menikmati.

Hasil penelitian ini juga mengungkapkan bahwa cara partisipan terpapar berita juga mengambil peran dalam praktik news fatigue ini. Partisipan yang secara sadar mengakses sendiri portal berita untuk mendapatkan informasi, lebih sedikit yang melaporkan news fatigue terhadap banyaknya berita. Sedangkan, partisipan yang lebih sering mengakses berita karena mengalami incidental news exposure lebih banyak yang melaporkan news fatigue terhadap banyaknya berita. Partisipan yang lebih sering terpapar berita secara tidak sengaja ini juga lebih sulit menghindari berita meski merasa lelah dengan banyaknya berita karena berita terus menghampiri mereka.

Kategori berita yang melelahkan bagi partisipan laki-laki maupun perempuan juga berbeda. Audiens perempuan merasa jenuh dan lelah dengan berita yang membahas COVID-19. Alasannya, berita COVID-19 kebanyakan bernada negatif dan dibahas terus-menerus. Menurut mereka, seringkali berita-berita ini membuat mereka khawatir, takut, waspada, dan cemas, terlebih pekerjaannya sehari-hari juga melelahkan secara emosional, terutama mereka yang bekerja sekaligus masih harus mengurus anak. Temuan ini mengungkapkan bahwa beban ganda bagi perempuan yang bekerja dan mengurus anak tidak hanya berpengaruh terhadap keputusan menghindari berita, tetapi juga dalam praktik news fatigue.

Partisipan perempuan mengaku bahwa mereka mengalami news fatigue karena topiknya yang dibahas terus-menerus dalam jangka waktu yang cukup lama. Mereka menganggap berita COVID-19 jadi monoton karena dibahas setiap hari. Pada awalnya para partisipan yang melaporkan kelelahan ini mengaku sangat intens membaca berita COVID-19 di dalam negeri. Namun setelah dua minggu ini (selama proses pengumpulan data), mereka mendapati berita COVID-19 semakin menjenuhkan dan melelahkan untuk diikuti. Berita dengan topik yang dibahas terus-menerus ini dapat menjadi penghalang bagi partisipan untuk mendapat pemahaman yang baik. Mereka jadi kehilangan interest sehingga berita kehilangan fungsinya.

Sejumlah partisipan perempuan merasa lelah dengan berita yang informasinya hanya diulang-ulang dan tidak ada update terbaru. Seperti dalam berita COVID-19 yang selalu jadi bahasan utama dan kebanyakan beredar adalah berita mengenai jumlah korban COVID-19. Mereka juga mengatakan lebih menyukai berita yang dapat menyajikan sudut pandang baru dalam membahas sebuah topik, misalkan dari perspektif human interest. Sedangkan bagi partisipan laki-laki, mereka tidak merasa lelah dengan berita COVID-19 meski bernada negatif dan dibahas terus-menerus, bahkan cenderung tertarik untuk mengikuti terus berita ini. Alasannya, berita tersebut penting untuk menambah wawasan dan pengetahuan sehingga lebih mawas diri. Setidaknya, kesadaran semacam ini dapat membekali diri mereka dengan 
Volume 05 Nomor 01 Tahun 2021

DOI: $10.24198 / j k j . v 5 i 1.31587$

kewaspadaan yang lebih soal penyebaran virus corona di sekitar mereka.

\section{SIMPULAN}

Peneliti menemukan bahwa gender masih menjadi faktor penting dalam memahami perbedaan praktik konsumsi berita, FOMO, dan news fatigue. Dalam konteks konsumsi berita di masa pandemi COVID-19, setidaknya motif penggunaan media serta gender dari audience tersebut dapat membedakan bagaimana mereka memahami news fatigue. Penelitian ini juga mengungkapkan bahwa partisipan yang lebih sering mengakses berita karena incidental news exposure lebih banyak yang melaporkan news fatigue. Mereka yang lebih sering terpapar berita secara tidak sengaja ini juga lebih sulit menghindari berita meski mereka merasa lelah. Hal ini karena berita terus menghampiri mereka. Hasil penelitian juga menunjukkan bahwa faktor jenis pekerjaan dan beban ganda antara bekerja dan mengurus anak-anak memainkan peran penting dalam membatasi konsumsi berita COVID-19 oleh partisipan.

Dari hasil penelitian juga dapat dilihat bahwa lebih banyak partisipan perempuan yang merasakan news fatigue. Akan tetapi, penelitian ini harus dipahami dalam konteks sejumlah keterbatasan. Misalkan bahwa data yang digunakan oleh peneliti hanya mengandalkan media diary dan wawancara mendalam. Sehingga, penelitian selanjutnya perlu mengembangkan metode lain seperti field observation ataupun survei guna mendapatkan perspektif yang berbeda soal fenomena FOMO dan news fatigue. Selain itu, karena penelitian ini terbatas hanya dilakukan pada partisipan yang berdomisili di Jakarta serta hanya melihatkan kaum urban dan kelas menengah, maka peneliti selanjutnya dapat melakukan penelitian serupa di wilayah lain untuk membandingkan praktik news fatigue berdasarkan gender dengan memperhatikan dinamika, konteks sosio-kultural serta hambatan struktural lainnya dalam hal konsumsi berita.

\section{DAFTAR PUSTAKA}

Abel, J. P., Buff, C. L., \& Burr, S. A. (2016). Social media and the fear of missing out: Scale development and assessment. Journal of Business \& Economics Research (JBER), 14(1), 33-44. https://doi.org/10.19030/jber.v14i1.9554

Altintas, E., \& Sullivan, O. (2016). Fifty years of change updated: Cross-national gender convergence in housework. Demographic Research, 35(1), 455-470. https://doi. org/10.4054/DemRes.2016.35.16

Benesch, C. (2012). An empirical analysis of the gender gap in news consumption. Journal of Media Economics, 25(3), 147-167. https://doi.org/10.1080/08997764.2012.700976

Fortunati, L., Deuze, M., \& de Luca, F. (2014). The new about news: How print, online, free, and mobile coconstruct new audiences in Italy, France, Spain, the UK, and Germany. Journal of Computer-Mediated Communication, 19(2), 121-140. https://doi.org/10.1111/ jec4.12017

Gil de Zúñiga, H., \& Diehl, T. (2018). News finds me perception and democracy: Effects on political knowledge, political interest, and voting. New Media \& Society, 21(6), 12531271. https://doi.org/10.1177/1461444818817548

Gottfried, J. (2020). Americans' news fatigue isn't going away - about two-thirds still feel worn out. Diakses dari Pew Research Center website: https://www.pewresearch.org/ fact-tank/2020/02/26/almost-seven-in-ten-americans-have-news-fatigue-more-amongrepublicans/

Gulyas, A., O'Hara, S., \& Eilenberg, J. (2019). Experiencing local news online: Audience practices and perceptions. Journalism Studies, 20(13), 1846-1863. https://doi.org/10.10 80/1461670X.2018.1539345 
14 | Kajian Jurnalisme

Volume 05 Nomor 01 Tahun 2021

DOI: $10.24198 / j \mathrm{kj} . v 5 i 1.31587$

Lee, A. M. (2013). News audiences revisited: Theorizing the link between audience motivations and news consumption. Journal of Broadcasting and Electronic Media, 57(3), 300-317. https://doi.org/10.1080/08838151.2013.816712

Nelissen, P., Konig, R., \& Karsten, R. (2008). Occupational position and consumption of news: a research note. Communications, 33(4), 473-484. https://doi.org/10.1515/ COMM.2008.029

Newman, N., Fletcher, R., Kalogeropoulos, A., Levy, D., \& Nielsen, R. K. (2017). Reuters Institute digital news report 2017. Oxford: Reuters Institute for the Study of Journalism.

Palmer, R., \& Toff, B. (2018). From news fatigue to news avoidance. Diakses dari NiemanLab website: https://www.niemanlab.org/2018/12/from-news-fatigue-to-news-avoidance/

Poyant, J. (2016). Fear missing out? No wonder you've got information overload. Diakses dari TheWorld website: https:/www.pri.org/stories/2016-01-27/fear-missing-out-youve-gotinformation-overload-may-help

Schrøder, K. C. (2016). The nature of news avoidance in a digital world. Diakses dari Digital News Report website: https://www.digitalnewsreport.org/essays/2016/nature-newsavoidance-digital-world/

Schumann, C. (2018). Essay: Is topic fatigue an international problem? Four theses. Global Media Journal, 8(2), 1-12. https://doi.org/10.22032/dbt.37780

Selva, M., \& And1, S. (2020). Women and news: an overview of audience behaviour in 11 countries. Oxford: Reuters Institute for the Study of Journalism.

Taneja, H., Wu, A. X., \& Edgerly, S. (2018). Rethinking the generational gap in online news use: An infrastructural perspective. New Media and Society, 20(5), 1792-1812. https:// doi.org/10.1177/1461444817707348

Tewksbury, D., Weaver, A. J., \& Maddex, B. D. (2001). Accidentally informed: Incidental news exposure on the world wide web. Journalism and Mass Communication Quaterly, 78(3), 533-554. https://doi.org/10.1177/107769900107800309

Toff, B., \& Palmer, R. A. (2019). Explaining the gender gap in news avoidance: "News-Is-forMen" perceptions and the burdens of caretaking. Journalism Studies, 20(11), 1563-1579. https://doi.org/10.1080/1461670X.2018.1528882

Yin, R. K. (2018). Case study research and applications: Design and methods. New York: SAGE Publications, Inc. 